\title{
Climate change and post-politics: Repoliticizing the present by imagining the future?
}

\author{
Anneleen Kenis ${ }^{1}$ and Erik Mathijs \\ Department of Earth and Environmental Sciences, KU Leuven, Belgium
}

This is the accepted version of an article which has been published in 'Geoforum'. Check the following website for the final, published version: http://dx.doi.org/10.1016/i.geoforum.2014.01.009

To cite this article: Kenis A., Mathijs E. (2014). Climate change and post-politics: repoliticising the present by imagining the future? Geoforum, 52, 148-156

\footnotetext{
$1 *$ Corresponding author. Email: Anneleen.Kenis@ees.kuleuven.be. Postal address: Anneleen Kenis, Department of Earth and Environmental Sciences, Celestijnenlaan 200E - bus 2409, 3001 Heverlee, Belgium.
} 


\title{
Climate change and post-politics:
}

\section{Repoliticizing the present by imagining the future?}

\begin{abstract}
Several scholars have criticized the predominant post-political representations of our current era, particularly with regard to climate change. However, what happens when a movement explicitly aims at repoliticizing the present in an attempt to open a space for change? Combining scholar activism with theoretical insights from post-foundational political theorists, such as Jacques Rancière, Chantal Mouffe and Ernesto Laclau, this paper studies the paradoxical nature of the attempt to repoliticize climate change by Climate Justice Action (CJA), a grassroots movement that was set up before the Copenhagen climate summit in 2009. Comparing different repoliticization strategies, the paper shows how CJA exhibits core features of a Rancièrian political act by focusing on making visible what was previously invisible by acting on the postulate of equality. However, lacking an elaborate perspective on alternatives, both Rancière and CJA appear to be stuck in the present. Drawing on Mouffe and Laclau's discourse theory, the paper subsequently analyzes the nodal points of CJA's discourse that could function as inscription points for alternatives. Yet, these points appear to primarily intensify a we/them distinction. The result is a paradox: to create a space for imagining alternative futures, one must first fight post-political representations of the present. However, when politicization becomes an end in itself, the outreach of the movement, and therefore its capacity to repoliticize and stimulate the imagination of alternative futures, is constrained.
\end{abstract}

Keywords: climate justice; post-politics; repoliticization; direct action; system change; Jacques Rancière; Chantal Mouffe; Ernesto Laclau

\section{Introduction}

Over the last two decades, an important debate has taken place in political theory concerning our current 'post-political' or 'post-democratic' condition (Crouch, 2004; Marchart, 2007; Mouffe, 2002b, 2005, 2006; Rancière, 1998; Žižek, 2000). Broadly speaking, this condition implies that predominant representations of society tend to be consensual or technocratic and thus make power, conflict and exclusion invisible. As Chantal Mouffe (2002a, p. 33-34) has argued, this is a threat to democracy: 'Instead of trying to erase the traces of power and exclusion, democratic politics requires us to bring them to the fore, to make them visible so that they can enter the terrain of contestation'.'

This topic has also received significant attention in the fields of geography and ecology, primarily with regards to climate change, an issue that is particularly vulnerable to being represented in a post-political way, as Erik Swyngedouw (2007; 2010a; 2013) has shown. Many authors in these fields have focused on the post-political thesis, either to criticize it (e.g., Chatterton et al., 2013; Featherstone, 2013; Featherstone and Korf, 2012; North, 2010; Urry, 2011) or apply it to specific cases (e.g., Bettini, 2013; Brand et al., 2009; Celata and Sanna, 2012; Goeminne, 2010, 2012; Mason and 
Whitehead, 2012; Neal, 2013; Oosterlynck and Swyngedouw, 2010; Kenis and Mathijs, 2009; forthcoming). A question that has received much less attention, however, concerns what happens when an actor explicitly tries to repoliticize the present to realize the change that the actor has deemed necessary. This is the topic of the present paper: the study of the Climate Justice Action movement (CJA) as one of the most prominent movements in recent history that explicitly took issue with the consensual, post-political logic governing much of the debate on climate change." CJA emerged in the year prior to the 2009 Copenhagen climate summit and consisted of a broad range of groups and activists from around the world and especially from Western Europe."' After the summit, many CJA groups remained active, setting up various types of activities (e.g., actions around specific issues such as the investments by banks and companies in the exploitation of tar sands or shale gas and larger events such as climate camps), campaigning around the summits in Cancún, Durban and Qatar and engaging in a myriad of education and information initiatives. At the same time, the movement slowly disintegrated.

Interestingly, CJA did not merely advocate a specific cause, as all social movements do: CJA also targeted post-politics as an obstacle for promoting this cause, and this difference is what makes it such a relevant object of study. CJA criticized the fact that in a post-political condition, alternative voices are at risk of remaining unheard. The movement did not merely wage a concrete political struggle about a specific issue, but it also engaged in a type of meta-struggle for genuine political struggle and disagreement to even become possible and visible (Kenis and Lievens, 2014). Thus, it aimed to create a space in which political plurality, power differentials, conflicts and oppositions would become visible, and it considered this condition to be essential for tackling climate change in an effective, democratic and socially just way. In this way, CJA attempted to repoliticize the debate on climate change, and it was quite explicit concerning this goal (COP15zine, 2009).

In this paper, we will attempt to spell out the difficulties and obstacles that confront such an endeavor. We elaborate two possible strategies of repoliticization: one based on the work of Jacques Rancière and the other on the writings of Chantal Mouffe and Ernesto Laclau. On the basis of our involvement as scholar activists within the movement, we will discuss CJA's practices and discourses from the perspective of these two strategies and spell out the challenges and obstacles the movement was confronted with in its attempt to repoliticize the public sphere. We will pay particular attention to

\footnotetext{
"CJA was launched as a network; however, throughout the meetings, activities and organized actions, it became more than that. CJA began to attract people who were not members of one of the founding organizations, and many activists started to identify with CJA as such. In the interviews we conducted, almost all activists spoke of CJA as 'a movement' with which they strongly identified. For that reason, we chose to describe CJA as a movement in this paper, even if it was originally constituted as a network.

III CJA was of course only one organization in a broader field of climate justice articulations, alliances and movements. The claims made in this paper are only aimed to represent CJA in the strictest sense, in particular regarding its current Flemish incarnation. For additional information on the background and activities of the movement, see Chatterton, Featherstone and Routledge (2013) and Featherstone (2013).
} 
the role of visioning the future as a crucial element in any attempt to repoliticize the present. The paper concludes by analyzing the paradoxical nature of CJA's project to repoliticize in the context of post-politics, which helps to explain its relative failure.

\section{Research design}

Our research combined a theoretical exploration of strategies for repoliticization with scholarly activism or action research (Brydon-Miller et al., 2003; Reason and Bradbury, 2008; the Autonomous Geographies Collective, 2010), the confrontation between which allowed us to assess these strategies on the basis of the actual experiences and discourses of an existing movement.

As scholar activists involved with CJA, we involved in a movement with others, which required us to set up meetings, engage in strategic debates and actions and perform practical tasks while at the same time, clearly identifying ourselves as scholars. ${ }^{\text {IV }}$ Concretely, we attended more than 40 meetings, activities, demonstrations and actions, both in Belgium and internationally, and actively contributed to organizing and promoting these activities. This involvement took place in the year prior to, during and after the climate summit in Copenhagen (including an international preparation weekend in Copenhagen in October 2009 and a stay of ten days during the Copenhagen summit itself), spanning the lifetime of the movement's relatively short and active existence. After the Copenhagen summit, we closely followed the activities of the movement but did not remain as actively involved. However, we analyzed an extensive range of leaflets, press releases, booklets and other materials spread by the movement, and to complete our data triangulation, we conducted 20 in-depth interviews with activists who were actively engaged in the Belgian wing of CJA and 20 in-depth interviews with activists from Transition Towns, another grassroots climate movement that arose in the same period in Belgium and had an attitude similar to CJA regarding conventional environmental approaches, although it opted for a much more depoliticized trajectory than CJA. ${ }^{\vee}$ The latter interviews made it possible to add an outsider's point of view, as one of the central questions during the interviews with Transition Towns members was how they perceived CJA. Although CJA was organized on the national level in Belgium, all activists we interviewed were from its Flemish contingent. We opted for 'maximum variation sampling' to discover the most comprehensive spectrum of backgrounds and viewpoints within the

\footnotetext{
IV Only the first author of this paper was engaged as a scholar activist in CJA. However, for practical reasons, we will speak in the plural form 'we' throughout the paper.

${ }^{v}$ It should be noted that CJA and Transition Towns are both grassroots climate movements that share some features (they both criticise the market approach of conventional environmentalism (e.g., green growth), they conceive of people as citizens rather than as consumers, and they focus on collective instead of individual change) while strongly diverging on several other dimensions. In contrast to CJA, Transition Towns stresses the importance of localization, resilience, cooperation and the psychology of change, and it firmly rejects every 'we against them' discourse (which, as we will see below, is characteristic of CJA) (Kenis and Mathijs, 2009; forthcoming).
} 
movement (Patton, 2002). The interviewees were of various ages, education and ideological backgrounds. We also attempted to include a maximum range of opinions and positions as they were articulated during meetings, actions and activities. Eleven female and nine male activists were interviewed. Of course, the 'sample' was also influenced by the activists' willingness to be interviewed. However, only two activists refused. In qualitative research, whose goal is not to arrive at generalized statements, samples do not necessarily have to be representative. However, because of the relatively small number of people who were actively involved in CJA, our sample could be observed as quite representative of the voices and perspectives that existed among the Flemish CJA activists.

The interviews consisted of semi-structured, open-ended questions that focused on the subject's motivations to engage in CJA, the characteristics of CJA, the similarities and differences between CJA and other movements, opinions on root causes of climate change, alternatives and strategies, and more specifically, on COP 15, direct action, violence, companies, politicians and the choice for consensus decision making (several of these topics fall outside the scope of this paper). All interviews lasted between one and two hours and were digitally recorded, fully transcribed, coded and analyzed in detail with the help of the software program NVIVO ${ }^{\circledR}$ (Doncaster, Victoria, Australia).

The use of interviews in combination with document analysis and our involvement in the movement as scholar activists enabled us to develop a thick and rich image of the movement (Baxter and Eyles, 1997; Patton, 2002). The trends and thematic findings resulting from this analysis will be discussed in the sections below.

The goal of our research was to develop an understanding of the elements that facilitate or impede a repoliticization of climate change, which required our research to be strongly theoretically informed. Evidently, the theoretical discussion on 'the political,' post-politics and depoliticization is quite rich and includes a diversity of voices and perspectives. From the broad spectrum of theories developed within the framework of post-foundational political theory, the work of Jacques Rancière (1998; 2001; 2006) and the discourse-theoretical approach informed by Chantal Mouffe (2006) and Ernesto Laclau (Laclau, 1990; see also Laclau and Mouffe, 2001) and further developed by David Howarth, Aletta Norval and Yannis Stavrakakis (2000) appeared as crucially important to our analysis. The choice of these approaches was informed by both theoretical and empirical considerations, and through a continuous process of examining theory and empirical data, we singled out these two approaches because they appeared best suited to describe repoliticization as conducted by CJA and to analyze the obstacles and challenges the movement was confronted with.

This is not to suggest that both concepts of political action or repoliticization are compatible. Although CJA integrates elements of both strategies, it must be stressed that the latter diverges in essential aspects, including the role of alternatives. As we will show below, it is the juxtaposition of both approaches that helps us acquire a better grasp of the specificities and limits of CJA's attempt at repoliticization. This also implies that our analysis slightly diverges from that of scholars such as Slavoj Žižek (2000), who often combines elements of both Rancière and Mouffe and Laclau without fully taking into account the differences that exist between them.

\section{Two strategies of politicization}

\subsection{Rancière: making visible what was invisible}


The atmosphere we encountered during the climate summit in Copenhagen (both in and around the conference venue itself, such as on billboards, in press articles and in the slogans of mainstream NGO's, resembled what Rancière has described as post-democracy or consensual democracy. 'Consensual democracy,' he writes, 'is a reasonable agreement between individuals and social groups who have understood that knowing what is possible and negotiating between partners are a way for each party to obtain the optimal share that the objective givens of the situation allow them to hope for and that is preferable to conflict' (Rancière, 1998, p. 102). In other words, everyone is turned into a partner in an apparently open deliberation. As a result, dissensus is obliterated, the contingency of the present is rendered invisible and alternative voices remain unheard. According to Rancière (2007b, p. 12), each situation is characterized by a specific 'distribution of the sensible,' which refers to a configuration that only makes certain things visible or sayable. In a regime of postdemocracy, this distribution of the sensible functions in such a way as to make exclusion unthinkable even if it is constitutive. It then appears as if there is nothing beyond what is actually visible and sayable, and this is how we can conceive of post-politics from a Rancièrian perspective.

Politics, in contrast, is what subverts this situation. It disrupts the distribution of the sensible. It entails the manifestation of a 'part of those who have no part,' which contests and discloses exclusions and in doing so, makes something new visible (Rancière, 1998, p. 9). In other words, political action is concerned with creating a space where something new can be heard or seen. This is also, according to Rancière, what genuine democracy is about: creating a space where the unnamed and uncounted become named and counted. This space arises when a group of people ruptures its invisibility and decides to act on the assumption of equality. People then act as if they are equal to the powerful, and by doing so, they are able to generate certain effects within the distribution of the sensible.

The notion of equality is of central importance in Rancière (1998). Each social order, he argues, is hierarchical while being paradoxically based on a fundamental equality. Even producing an order, which is the hierarchical act par excellence, presupposes a basic form of equality, specifically the equality of intelligences. Giving an order could not be successful if the subordinate person is not capable of understanding and interpreting the order by making use of language and her intelligence in the same way as the superior person. Political action, according to Rancière, is bringing this underlying equality to the surface: it entails acting apart from the (hierarchical) roles attributed by the social order and according to the assumption that all are equal. The most salient example of political action provided by Rancière is Rosa Parks' refusal to give up her bus seat to a white person. Through such radical acts, the distribution of the sensible is disturbed and something new becomes visible. This specific conception of political action is not about realizing an alternative social order; it is a theatrical performance that disrupts the inequalities of the social order by exhibiting a more fundamental equality.

\subsection{Mouffe and Laclau: counter-hegemony}

Chantal Mouffe's and Ernesto Laclau's approach to repoliticization also starts from a constitutive notion of exclusion. A social order, Mouffe (2006) argues, is constituted by hegemonic practices that always repress certain possibilities and activate others. However, the exclusions that are constitutive of every hegemony generate antagonisms that can become the starting points for the articulation of counter-hegemonic practices. Because exclusion is constitutive, antagonism is unavoidable: the political, therefore, is an ontological dimension of social relations. 
Certain discourses, however, misrecognize this dimension, and post-politics is the result. The problem, according to Mouffe $(2005,2006)$, is that antagonisms can be tempered or constrained only when they are fully acknowledged. Through their acknowledgment, antagonisms can be turned into 'agonisms,' whereby opponents recognize each other as adversaries rather than full-blown enemies. According to Mouffe, this is a crucial feature of democracy. If antagonisms are misrecognized, the opponent tends to become invisible or is criminalized, which pushes the relation of adversity to extremes.

Within this framework, repoliticization consists of what Laclau and Mouffe (2001) have called the articulation of a chain of equivalences against the prevailing hegemonic order (see also Howarth, 2000; Howarth and Stavrakakis, 2000). This entails the equivalential grouping of a series of demands under a core signifier or nodal point (such as 'Solidarity' in the case of the Polish workers' movement in the 1980s [Laclau, 2005]). This core signifier evolves to represent an entire series of demands, with a collective identity forged around it. Thus arises a we/them distinction that Mouffe and Laclau described as the hallmark of 'the political.' For Mouffe (2006), democracy can only be safeguarded through the visible existence of a plural and conflictual space of encounter between different hegemonic and counterhegemonic discourses.

\subsection{Divergences}

Within the framework of this paper, we cannot delve into the intricacies of the philosophical divergence between Rancière's (2007b) innovative 'aesthetic' theory of politics and the poststructuralist approach of Mouffe and Laclau (2001). For our purposes, it suffices to describe several core differences. Mouffe (2006) stresses the importance of collective identities, and therefore requires a concept of representation that inevitably entails a certain inequality and the exercise of power. Rancière, however, focuses on the effects of people acting as if they are equal (Hallward, 2006). Such actions imply that individuals subtract themselves from the identities and roles attributed to them by the existing social order (Rancière, 1998; see also Dikeç, 2012). His aim is not the construction of an alternative collective identity but disidentification and the manifestation of the equality underlying every social relation. If there is a collective subject in the Rancièrean political act, it is not based on identity but on the refusal of identity.

The crucial difference between both approaches, however, is their relation to the construction of an alternative social order. Mouffe's $(2000,2006)$ counterhegemonic practices are intended to embody a future alternative for the existing order. For Rancière (1998), however, genuinely political action constitutes an event in the present (this focus on the present is one reason why space becomes more interesting than time from a Rancièrian perspective (Dikeç, 2005, 2012, 2013)). From the moment one begins to build an alternative order, one also begins to construct an inevitably inegalitarian 'distribution of the sensible.'

We thus arrive at two possible 'models' of politicization: one in which the political resides in the plural space of encounter between different projects (including certain demands, visions of future alternatives and strategies) and the other in which politicization occurs as a result of acts of disidentification and subversion of the existing distribution of the sensible. In this paper, we will use both frameworks to shed light on the way CJA attempted to repoliticize climate change. We will argue that while CJA produced discourse that can be described in terms of the discourse-theoretical approach of Laclau and Mouffe, the movement epitomized the Rancièrian political act: subversion aimed at making visible what was invisible in the consensual logic of the climate summits by acting 
under the postulate of equality. CJA thus focused less on alternative hegemonic projects and more on enabling new voices to be heard. As we will show, this was at once its strength and its weakness, especially when winning over enough people for an alternative political project was at stake. In a way, the limits of Rancière's notion of the political act mirrored the limits of CJA's attempt to repoliticize.

\section{Politicization and its limits}

To analyze CJA's discourse in terms of its relation to the political, we will make use of a set of distinctions that Bjarne Bruun Jensen (2002; 2004) introduced in the domain of environmental education. Jensen distinguishes between four dimensions that environmental education can consist of: (1) the nature of the problem and its effects, (2) the human-societal root causes, (3) strategies for change and (4) visions and alternatives. Jensen's thesis is that mainstream environmental discourses focus too exclusively on the first dimension, whereas democratic, emancipatory and action-oriented discourses have to encompass all four. As we will show in the following, this fourfold distinction is particularly useful for delineating the differences between environmental discourses, particularly in terms of the place they attribute to the political.

\subsection{From the nature of the problem to the root causes}

Hegemonic climate discourse clearly focuses on the nature of the climate problem and its effects, and this is the dimension that is nearly absent in CJA's discourse. Climate justice activists Ulrich Brand, Nicola Bullard, Edgardo Lander and Tadzio Mueller critically noted that 'In spite of its obviously political nature, the issue of climate change is often perceived as a question of science rather than politics,' (2009, p. 11). This critique of the one-sided focus on science in mainstream discourses is shared by scholars: 'For more than 15 years now,' Gert Goeminne (2010, p. 208) states, 'the IPCC panel has been trying to frame the climate issue as a scientific puzzle.' This is manifested in the focus on $\mathrm{CO}_{2}$ in the famous slogan of the British government: 'Act on CO2' (Urry, 2011, p. 90). Being the central nodal point of mainstream discourse, $\mathrm{CO}_{2}$ comes to stand for the entirety of the catastrophe we are facing: thus, to avoid catastrophe, we simply have to reduce $\mathrm{CO}_{2}$ emissions (Swyngedouw, 2007; 2010a). The result is a strange type of pseudo-politicization wherein conflict and struggle are occurring with an externalized and socially disembodied enemy such as $\mathrm{CO}_{2}$, against which we all appear to be united. The focus on $\mathrm{CO}_{2}$ narrows the debate to ignore the human-societal root causes and processes of change and focus on technical solutions that remain within the parameters of what currently exists. Such discourses have depoliticizing and disempowering consequences (Wynne, 2010). As David Demeritt (2001, p. 329) argues, 'the highly technical and undifferentiatedly global basis of its appeal simply turns people off.'

CJA, in contrast, explicitly tried to politicize climate change by broadening the frame: 'it is not just about $\mathrm{CO}_{2}$ ' but also about 'land grabs, state repression, corporate control, carbon trading, neocolonialism' (CJA-Leaflet, 2009b). As Alice, one of the activists we interviewed, explained: 'I think traditional environmental movements have little to tell about the cause of the environmental problem. Of course one can say that the climate is heating because we emit too much $\mathrm{CO}_{2}$. But why is that? Why 
did we evolve towards a society that needs to emit so much $\mathrm{CO}_{2}$ in order to function? If you try to answer that question, you start to question the system as such.' ${ }^{\prime v 1}$

This observation led many CJA activists to state that climate change is not so much a problem of nature but of society. 'Why climate change is not an environmental issue,' reads the title of a CJA booklet (2009), implying that it is impossible to tackle climate change without fundamentally questioning the way our current society is organized. Furthermore, by pointing to the heterogeneity of and the antagonisms that cut through the concept of 'the people' (Swyngedouw, 2010a), CJA explicitly dismissed the rhetoric of 'all together against $\mathrm{CO}_{2}$.'

In contrast to hegemonic discourses, CJA strongly focused on the second dimension: the root causes of climate change. It was also on this level that CJA particularly aimed at repoliticizing climate change, pointing to capitalism and its fundamental structures as its root cause (CJA-Leaflet, 2009a, 2009d). For example, the title of a CJA leaflet (2009d) reads: 'Climate change is a symptom, capitalism the crisis.' As Alexis put it: 'companies, clever politicians and supranational institutions remain within a capitalist framework. And I don't think just and sustainable solutions will come within that system you know, you then get situations as in Copenhagen, where carbon trading is being promoted.'

\subsection{Strategies}

Concerning the third dimension, which is strategies, the dominant discourses are liberal, managerial and technocratic (Demeritt, 2001; Kenis and Lievens, 2014; Swyngedouw, 2007; 2010a). They are concerned with creating new markets and commodities (emissions trading or developing a 'green' sector in the economy), creating new techniques or maintaining old ones, such as nuclear energy, and sustainable consumption (Kenis and Lievens, forthcoming). Interestingly, all these strategies were explicitly dismissed by CJA. Even individual behavior change, as promoted by many NGOs, was waved aside by CJA's activists. As Paul Sumburn (2010, p. 39) aptly articulated in a book edited by the activist Turbulence Collective: 'It's important that, where they can, people make individual changes, but switching light bulbs doesn't connect a person with real causes of climate change, the political and economic system.' 'Forget shorter showers. Why personal change does not equal political change,' reads the title of an article written by Derrick Jensen (2009) in a booklet edited by CJA activists. Many of the activists we interviewed made a similar point. Stacy, for instance, criticized the dominant approach as follows: 'I've had quite an allergic reaction to it for a while. [...] You know, you have to become aware of the climate, and what you can do about it yourself is to buy green products. But there is a bigger picture, you know, and that is what I find important.' Alice noted, 'It is simply much more structural; it is the system you have to question and not whether you go shopping by car or not.'

Strategically, CJA aimed at empowering people and actively involving them in a struggle against the root causes of climate change. In a widely distributed CJA booklet $(2009$, p. 1), people are urged to 'join together in taking control over our lives and real solutions ...' Many activists related their struggle with feelings of powerlessness before they joined CJA or similar movements (Kenis and Mathijs, 2012). Kenneth explained:

\footnotetext{
${ }^{V I}$ All first names used in this section refer to activists we interviewed. They have been modified for reasons of anonymity.
} 
'You have a certain image of society, and you want to change things, but you feel powerless. You know that things don't change automatically. Starting from this experience of powerlessness, however, you start to question what the limits are and whether there are other people who have the same experience, and then ... slowly, ideas emerge about possible actions. First, you search for things with a low threshold, which are not or not very confrontational, and then, well, you start to go further.'

To realize its goals, CJA deliberately opted for more adversarial and confrontational strategies, such as direct action. As was stated in a CJA booklet (2009, p. 24): 'creating and defending real solutions from below will not come without a struggle.' In the words of Timothy: 'the reason why direct action is absolutely necessary is that there are a number of established interests that do all they can to maintain the status quo - and the status quo will not be challenged by encouraging people to go shopping by bike.' Therefore, Timothy argued, more confrontational strategies are necessary. Alexis echoed the sentiment: 'When do companies become afraid? Not when someone starts to negotiate with them, but when their property is being threatened.' According to her, direct action is the adequate response to the challenges we are confronted with today.

Moreover, direct action, as conceived by CJA in a Rancièrian fashion, is not only about engaging in conflict but also about making something visible or audible that formerly remained hidden. The Reclaim Power action at the Copenhagen summit was a case in point: the action started from the idea to enter the conference venue under the assumption that the activists had as much right to speak as the diplomats and government representatives negotiating inside. Because this idea could not be fully realized, the activists decided to attempt to get as close as possible to the venue and to organize an alternative People's Assembly on its doorstep. Furthermore, they asked sympathetic conference delegates to walk out of the conference venue and join the alternative assembly. The aim was to create a space where alternative voices, such as indigenous people, trade unionists and women's groups from the Global South, could engage in a debate on a socially just climate agenda. In this way, they tried to 'produce a voice to those who are not being heard' at the summit (CJA-Leaflet, 2009c). As Tina underscored: 'Personally, I am especially in favor of the Reclaim Power action: to just stop the summit and then have people, especially from the Global South, who present their own agenda, so that it becomes possible to talk for once about what is really at stake.' As Beth emphasized: 'Well, the point is that you actually try to force them to listen to you. [...] The fact that you try to get so close and you really try to disturb the conference itself makes, perhaps, that these people inside will start to think: if they go this far, we have to take them seriously, if only for a minute.' According to CJA activists, such direct actions cannot be neglected and inevitably trigger a response by helping to put something on the agenda in an immediate and visible way. Jason stated: 'At least you will not allow the status quo to remain as it is. A simple demonstration can be neglected, but direct action cannot. An answer or a reaction is bound to come. Or it will be repression, or a kind of invitation to dialogue. But there will be a reaction.'

The Reclaim Power action also tried to bring visibility to other issues. For example, it aimed at 'breaking' the consensus ideology of the climate summit and turning the spotlight to what was neglected in the hegemonic discourse. As Gregory told us:

'What we actually wanted to do is to make visible to the whole world that there is a problem with the summit, that there is resistance against it, that there is critique. Symbolically, it is enormously important that everyone who watches the news understands that the summit is contested, that there are problems. Making that visible is the crucial thing which CJA is doing.' 
Almost all activists referred, implicitly or explicitly, to the necessity of making unheard voices hearable and invisible causes visible, to the breaking of consensus by showing what is present behind the 'superficial theatre of the climate summit' and to questioning the hierarchical distinction between those who are allowed to talk and those who have to stay outside the conference venue. Even when asked about the 'violence' that such actions sometimes trigger, many answered in similarly to Jason: 'The violence that will occur during such a summit to a large extent just embodies or displays what is actually structurally present.'

Furthermore, the choice for direct action was presented as crucial for democracy 'from below' (CJA-Booklet, 2009, p. 24). As Gregory explained, 'because of the enormous hegemony of the neoliberal market ideology and the enormous power of lobbyists, the only thing we can do to make our voices heard is to take radical action.' In this way, he claimed, direct action contributes to democratizing the public sphere and should be distinguished from the undemocratic practice of taking the law into one's own hands: 'You engage in civil disobedience not because you want to take the law in your own hands, but because you want to make a political point, you want to make something visible.'

\subsection{Alternatives}

With regard to the fourth dimension, which concerns alternatives, the picture is more complex, both for the hegemonic discourse and for CJA. To the extent that the future is captured in the hegemonic discourse, it is often either as a futuristic image of spectacular new technologies or as an apocalyptic threat (Swyngedouw 2010a). 'Now or never' was an often heard slogan during the Copenhagen summit, and the apocalyptic undertone was omnipresent. Quoting Goeminne (2010, p. 207): “"Copenhagen or the apocalypse" - that is how one might describe the atmosphere that ruled the build-up to the UN climate summit in Copenhagen in December 2009 [...]; not only would the climate change war be settled in Copenhagen, but the fate of humanity would too.' This type of observation led Swyngedouw (2010b, p. 308) to state that 'fear' is a 'crucial node through which much of the current environmental narrative is woven' and Žižek (2008, p. 1) to argue that ecology could become the 'new opium for the masses' that keeps 'the people,' who are benumbed by fear, silent and calm. The point is that when fear becomes the overwhelming sentiment, the space for asking fundamental political questions about our current society is strongly restrained. This situation can then be manipulated to impose an apparently broad consensus concerning a set of technocratic and marketdriven measures. Swyngedouw (2010a) notes that in contrast to other struggles, climate change has no positively embodied name or signifier. It does not posit positively embodied content with regard to the future, articulated vision, myth or imaginary ideal waiting to be realized. Climate change is only something one has to ward off "to make sure that things remain the same, that nothing really changes, that life (or at least our lives) can go on as before" (Cook and Swyngedouw, 2012, p. 1973).

CJA similarly dismissed apocalyptic imaginaries: 'Yes, we also feel the clock ticking, but we refuse to be rushed into draconian solutions that will only increase inequality and social injustice around the world' (CJA-Booklet, 2009, p. 1). However, an apocalyptic vision sometimes appeared in its discourse: 'The stakes have never been higher: revolution or death is the last scientific certainty' (CJABooklet, 2009, p. 24).

CJA left no doubt that capitalism had to be abolished to ward off catastrophe. However, if we asked activists what a post-capitalist society would look like or which alternatives CJA was fighting for, the answer was far less clear than when we asked questions about root causes or strategies. Thus, two 
observations can be made: visions of alternatives were either vague or they diverged widely. First, to the extent that they existed, visions of alternatives were rather vague. Several activists admitted that they did not know what an alternative would look like. Tina, for example, mused: 'Yeah, this is not so easy, of course. It is more easy to criticize the existing system than to invent something new or alternative ... In fact, I have no alternative, I don't know ... there will be many theories about this, without any doubt.' When asked about his vision of an alternatives, Kenneth explained:

'No, I don't have that, and I have to admit that I also struggle with that, eh, I think I consider myself as a postmodern human being or so [laughs]... I am having difficulties with whichever ideology, and I know that is also an enormous weakness because the effect is that you have less focus on your goal. The problem is that you want things to change, but you don't know how this could look like. I especially think it is important that it takes place in a very basic democratic way.'

Some activists stressed the need for 'system change' but had a hard time explaining what a different 'system' would look like. Kelly explained it as follows: 'Your production and economy should stand at the service of the well-being of the people and their environment,' but she admitted she could not say much more about it. Others stated that they did not believe in a blueprint, and that they considered having to articulate an alternative as a prerequisite to being able to formulate a critique of what exists to be an unfair expectation. Jason stated: ' $\mathrm{Hm}$, I do not believe in a blueprint. [...] I find it a bit an unfair critique - like, ok, you criticize current society, but what are your alternatives? No, I don't think you should have alternatives before one can formulate a critique. One can also formulate a critique out of concern.'

Second, to the extent activists were able to formulate visions of alternatives, they diverged widely: from living differently and more soberly in one's personal life to a democratically planned economy, from political reform to a change of mentality, from communal living and cooperative production to a stronger state. Some CJA leaflets made reference to demands such as keeping fossil fuels in the soil or establishing community control over production. Focusing on self-sufficiency and localization, Linda's alternative was one 'that we can live quietly in our own way, make our own products or buy them locally,' while Beth stated that she 'would rather evolve back towards communism.' Nick emphasized that he 'would reform politics, and promote a change of mentality.' However, he immediately added that 'it's difficult to make it concrete because we live in a complex society.'

Such a lack of focus on the development of an alternative social order is paramount to Rancière's conception of political action. In this sense, CJA's attempt to repoliticize follows Rancière's path. As we explained, for Rancière, the political is about action in the present. It is not about developing future alternative imaginaries. From the moment one attempts to realize an alternative social order, one starts to establish and fixate on a new distribution of the sensible, including new hierarchies and inequalities. Controversially, Rancière (2007a, p. 61) even distanced himself from radical alternatives such as self-management. In that sense, Rancièrian political action generates a space where conflict can appear, something new can be seen or heard and the unnamed can be named. However, it is not a space for what Swyngedouw (2010a, p. 229) calls 'the naming of different possible socio-environmental futures,' or the formulation of a 'new great fiction,' which can present an alternative to the current neoliberal hegemony, as Badiou (2005, p. 78) advocates (see also Swyngedouw, 2011). Following Rancière, the politicization of the present remains stuck in the present. This peculiarity of Rancière is also the likely Achilles heel of CJA. 
In the following section, we develop an analysis of CJA's discourse concerning alternatives (or the lack thereof) by approaching CJA from the perspective of Laclau and Mouffe's conception of politicization. As we explained earlier, this conception focuses on how a discourse is articulated around a number of demands for alternatives. We can read CJA's discourse from this perspective, and thus discover hints of the nascent counter-hegemony CJA might embody. However, we will also note that CJA's discourse is articulated around a number of elements that appear to epitomize alternatives for the future but that function to intensify the we/them distinction in the present.

\section{CJA's discursive nodal points}

Our analysis of CJA's discourse from the perspective of Laclau and Mouffe's (2001) framework yielded a straightforward result: CJA's discourse was centrally structured around three core nodal points. Central to CJA's discourse was a defense of 'climate justice', which was opposed to what it called 'false solutions' for climate change, such as nuclear energy, biofuels, carbon capture and storage and emissions trading (e.g., ClimateCollective, 2009; Müller and Passadakis, 2009; Virtanen, 2009). Stacy commented about this type of solution: 'They are stopgap measures. They don't question the cause of the problem.' Alexis expressed this position as follows:

'The solutions they propose are often worse than the current situation. Think about agrofuels - these are presented as green, but, I know it is perhaps a crude statement, but fossil fuels are probably less bad than agrofuels. With agrofuels, you simply create a food crisis, especially in the South. People become dependent, their land is being taken to produce fuel for us, etcetera. And on top of this, they can present this as a reduction of $\mathrm{CO}_{2}$ emissions and earn money with it. That is completely hallucinating, isn't it?'

Opposing these false solutions, CJA developed a counter-hegemonic discourse centered around the nodal point of 'climate justice.' From a discourse-theoretical perspective, we can state that through the construction of this nodal point, CJA attempted to organize and represent a variety of people and groups (from indigenous movements to workers unions and from no borders activists and landless farmers to anti-industrialists and peasant movements) within a broad alliance that linked climate politics with issues of social justice. Paul Chatterton, David Featherstone and Paul Routledge (2013, p. 615) wrote that for CJA, 'climate justice [...] functioned [as] a key discourse through that articulations were made between these diverse struggles.' Furthermore, many activists argued that they became interested and involved in climate activism because of this new focus on 'climate justice.' One could even say that for many, it was the 'justice' aspect rather than the issue of 'climate' that won them over to the struggle against climate change. Jason argued, for example, that 'Originally, I was one of those people who regarded the idea of a climate movement with a bit of suspicion [...], but with the emergence of the concept of climate justice, which added the justice aspect, this strongly changed.'

Many activists considered the idea of 'climate justice' as a starting point to rebuild or revitalize a previously existing broader movement for social justice, which many framed as the alterglobalization or global justice movement. Jason explained how he arrived at this idea by reading an article of Tadzio Müller (2008) in Turbulence:

'In this article, Tadzio Müller said the alterglobalisation movement has made a number of very valid points, but on this moment, it has lost its dynamic, and we now have to focus on the climate movement. Originally, I had a skeptical attitude towards this, but I started to 
understand the logic of it better and better. There was a truth to it. And then I thought: climate is indeed an actual topic, a hot item. It allows you to mobilize people, and you can bring that same story in a new way, a way which stands even closer to the people. Therefore it is actually a better way to convey the same fundamental social critique.'

Gregory made a similar argument when he stated:

'I think that what is also at stake, Copenhagen is a great chance to give a new boost to the global movement against neoliberalism and capitalism. The movement of antiglobalists that exists since ten years has known ups and downs. During the last years, the movement was a little bit less active, and so Copenhagen, for me, is also a chance to give that movement a new dynamic.'

Similar to many activists, both Jason and Gregory linked the concept of 'climate justice' with a strong focus on 'system change,' which could be identified as CJA's second nodal point. Similar to 'climate justice,' the notion of 'system change' was constructed to a large extent to realize a convergence between different struggles that all start from a system critique and plea for justice. As Jean-Francois told us, 'There are many themes around which you can become active, but climate actually symbolizes all other crises, and the definitive character of the climate crisis underlines more than anything else the horror of the current system.' Alexis explained her concept of climate justice as follows:

'The interesting thing is that all elements which require political action are united in the overarching denominator of climate change. Because basically it is about system critique, and the system manifests itself in several ways. Climate is one of them, and everything else can be subsumed under it.'

'System change' conveys different ends and meanings, as is typical for a discursive nodal point. It not only tries to bring different groups and struggles together, but it also refers to the fundamental transformation aspired to by CJA and the importance of attacking what CJA called the undemocratic 'circus' of the summit and the measures proposed by the official climate negotiators. Using 'system change not climate change' as a central slogan, CJA argued that the 'system' is the problem - not only as a root cause of climate change but also as the reason why the climate crisis is not being solved adequately (e.g., CJA-Leaflet, 2009d; ClimateCollective, 2009).

'Direct action' could be observed as a third nodal point, and was supposed to represent an adequate response to the need for climate justice and system change. With its focus on 'climate justice,' 'system change' and 'direct action,' CJA provides an example of a movement that tried to move beyond the post-political state of affairs with regard to climate change by publicly contesting the measures and approaches that are currently predominant, and by trying to build a counter-hegemonic discourse as an alternative. However, the question remains as to what extent these nodal points actually express a set of alternatives. As we will show, they actually function as a way to sharpen a we/them distinction rather than stimulate the imagination of genuine future alternatives.

\section{Alternatives for the future or antagonisms in the present?}

As Mouffe argues, the notion that 'there is no alternative' is a crucial element of today's postpolitical atmosphere: '[i]n fact, the main consequence of visualising our societies in such a "post- 
political" manner is to impede the articulation of any possible alternative to the current hegemonic order' (Mouffe, 2002b, p. 61). Of course, demanding 'system change' is an important step in repoliticizing the present. However, Mouffe (2002a, p. 7) suggests that repolitization requires, in addition, a 'debate in the democratic political public sphere about possible alternatives to the existing hegemonic order.' In other words, 'being against' is not enough for becoming political: one needs a constructive political project. Interestingly, an often heard critique of CJA is that it lacks such a project. As Sophie, a member of Transition Towns, stated: 'Yes, it is easy to criticize [...] but if you really want do something, you need a good alternative, and one that is workable. ${ }^{\prime} \mathrm{VII}$

The nodal points of 'climate justice' and 'system change' could function as a point of inscription for ideas about an alternative social order. However, as we showed, the actual demands they are supposed to represent are rather vague. Of course, as Mouffe and Laclau (2001) would argue, nodal points are inevitably tendentially 'empty' signifiers. In the case of CJA, however, this emptiness tends to become extreme. Furthermore, the coupling of the nodal points of 'climate justice' and 'system change' in CJA's discourse yields complex results. 'Climate justice' is a signifier that permits CJA to broaden itself and open up its discursive chain of equivalences to a wide variety of forces and demands. Even more moderate NGOs and policy bodies have been supporting 'climate justice' as a central demand for several years (De Lucia, 2009). However, this signifier has also made CJA's chain of equivalence inherently weak; it can easily be dislocated by other forces that also adopt the notion of climate justice and fill it with their own content, such as by equivalentially linking it to equal access to markets, the rule of law, or ensuring poor populations can also profit from carbon offsetting. Climate justice thus became a terrain of contestation (Chatterton et al., 2013). It is not surprising, therefore, that more radical voices began to criticize the concept of 'climate justice' as the possible starting point for more emancipatory climate politics (Featherstone, 2013).

'Climate justice,' however, acquired a political intensity in CJA's discourse through its linkage with 'system change,' which primarily expressed a strong position 'against' the current system rather than a vision of an alternative system, as our research indicated. The function of the signifier 'system change' is best described through Laclau's (1990, p. 61; see also Howarth and Stavrakakis, 2000) concept of 'myth,' which he defines as 'a space of representation which bears no relation of continuity with the dominant "structural objectivity.' In other words, myth creates a distance from what actually exists, and thus also contributes to demarcating a cleavage between 'us' and 'them.' This is also how the nodal point 'system change' functions in CJA's discourse: it establishes a radical discontinuity with the extant, dominant ideology.

However, there is a price to be paid for this is discontinuity. Because of the strong focus on political rupture, the chain of equivalence inevitably narrows again. Although 'system change' remained relatively empty in CJA discourse, many forces might have found it difficult to link up with CJA because their respective discourses lacked a reference to the 'system' and its transformation, let alone to radical forms of direct action that were presented as necessary.

However divergent the meanings attributed to 'system change,' the function of this signifier appear to remain the same: to sharpen one's opposition to the extant 'system' or to establish an antagonism, rather than promote a vision of a future alternative.

\footnotetext{
VII For more detailed analyses of the interviews with people from the Transition Towns movement, see Anneleen Kenis and Erik Mathijs (2009; forthcoming).
} 


\section{How to repoliticize the present?}

Interestingly, many environmentalists outside CJA tended to take a distance from CJA because of its politicized discourse. For instance, participants of the Transition Towns movement found CJA to be too radical, violent and extreme and based on a 'we against them' discourse. Sophie stated that 'When I first heard about it, the action aspect scared me a bit. I immediately imagined that these will almost be violent actions, to damage or overthrow certain things [...] and I don't like that, I don't like confrontation.' Marc is convinced that CJA is 'too extreme for mainstream people.' According to him, CJA's actions 'are no longer accessible for people' and 'disconnect people from the message.' Therefore 'they will not realize much.' This judgement was mainly based on his own experience within the movement; he once participated in a CJA meeting, but his proposals were dismissed for being 'too soft' and 'too calm.' The other activists argued that they 'had to go further if they wanted people to listen.' However, in his own opinion, it is exactly this radicalism that makes 'people will not listen anymore.'

Is CJA too extreme, radical and politicized? That is a possibility, but another hypothesis exists: in a post-political context, the chasm between 'common sense' and a strongly politicized discourse might simply be too large to bridge. People clearly have difficulties understanding a discourse whose explicit goal it is to repoliticize. This brings us to a paradoxical observation. Establishing a cleavage between one's own ideology and existing discourses is a crucial ingredient for repoliticization, but it can lead to minorization or an inability to gather people beyond the strongly convinced and politicized activists. As a result, movements such as CJA are confronted with a fundamental challenge: democratic change requires both politicization and the involvement of a large number of people. Both goals can be at odds with one another in post-political times. The central question is: how is it possible, within a post-political constellation, to broaden one's chain of equivalence without becoming post-political? This question points to an ambiguity that every struggle in a post-political era is likely confronted with: to fight for an alternative vision of society, one must first fight against post-politics. However, this can become an obstacle to broadening and strengthening the movement when politicization becomes an end in itself.

The fight against post-politics, including arguing for 'we-them' distinctions, is required, but it is not enough to establish the 'we' necessary to realize effective and democratic change, which can be illustrated by the following anecdote: CJA activists distributed leaflets in Copenhagen depicting the president of World Wildlife Fund (WWF), with the inscription 'WANTED' underneath. They denounced WWF for going too far in subscribing to the 'false solutions' of companies and governments, such as emissions trading. By radically attacking WWF's president, the activists attempted to make cleavages within the climate movement visible. They tried to show that there is a variety of 'environmentalisms,' and that 'being green' is not enough. In other words, they tried to politicize the climate struggle by turning the broad climate movement into a political space where different options can clash. However, many people who sympathized with CJA did not understand why it was so important to intensify these political divergences and why it was necessary to attack WWF instead of the 'real enemies,' such as big polluting industries or even climate change defined as ' $\mathrm{CO}_{2}$.' In other words, establishing cleavages is crucial for politicization, but when 'we-them' antagonisms becomes too strong or predominant, the chain of equivalence could become closed for new people, groups or demands.

The fact that CJA did not provide elaborate future alternatives appeared to contribute to this problem in an important way. Providing an alternative vision, it appeared, could have helped to correct 
the idea that repoliticization (establishing 'us versus them' distinctions) had almost become a goal in itself.

\section{Conclusion}

Intentionally pursuing repoliticization in post-political times is a highly paradoxical endeavor, and CJA embodied a number of the tensions involved. It attempted to demarcate a strong we/them distinction while simultaneously struggling with the question of how broad 'we' should be. At times, its fight against post-politics tended to overshadow the actual cause it was fighting for, at least to outsiders. CJA invoked the need for alternatives without always being able to spell them out concretely. As we explained, CJA's actions remained close to a Rancièrian conception of political action by attempting to make something visible that was previously invisible or to make unheard voices heard rather than advocating for a specific alternative social order. They accomplished this in the radical act of presenting themselves as negotiating partners on par with the official diplomats in the conference venue while at the same time demarcating a strong conflict line. This is a typically Rancièrian paradox: political action requires intense conflict to make oneself visible as a speaking agent who has equal standing with its adversary.

We further analyzed this conflictuality through the lens of discourse theory, which resulted in a number of nodal points, some of which seem to reference alternatives such as climate justice and system change. However, as we showed, these nodal points served to mark a cleavage with existing discourses. They were primarily aimed at repoliticizing the debate rather than starting a discussion on genuine alternatives.

CJA combined both repoliticization strategies in an unstable way: in a Rancièrian fashion, CJA activists attempted to make the circus of the negotiations visible and the unheard voices hearable and presented themselves as equals to the official negotiators at the Copenhagen summit. At the same time, however, CJA's lack of alternatives, which is typically Rancièrian, was not completely overcome via the discursive nodal points of climate justice and system change.

The end result is a paradox. Repoliticization is a condition for new movements to make their voices heard and realize social change. However, discourses aimed at repoliticization can have great difficulties in reaching out to broader audiences in post-political times. In these times, the desire and hope for an alternative and the belief in its possibility appear to be crucial preconditions for enthusing a critical mass of people for a political project. Making something visible that was previously invisible, as Rancière advocates, appears to be necessary, but it is not a sufficient basis upon which a movement can genuinely repoliticize because it risks preventing the movement from gaining a sufficient social basis. The problem is that one risks being perceived as politicizing for politicization's sake, which can end in a paradoxical situation in which this politicization is not taken seriously, thus undermining its own goal. Repoliticization engenders a strange dynamic: if the constitution of a 'we-them distinction' becomes too explicitly a goal in itself, then it appears to become more difficult to constitute a ' $w e^{\prime}$ ' at all. 


\section{References}

Badiou, A., 2005. Politics: a non-expressive dialectics, URBANOMIC. Birkbeck Institute for the Humanities, London.

Baxter, J., Eyles, J., 1997. Evaluating qualitative research in social geography: establishing 'rigour' in interview analysis. Transactions of the Institute of British Geographers 22 (4), 505-525.

Bettini, G., 2013. Climate Barbarians at the Gate? A critique of apocalyptic narratives on 'climate refugees'. Geoforum 45, 63-72.

Brand, U., Bullard, N., Lander, E., Mueller, T., 2009. Radical climate change politics in Copenhagen and beyond: From criticism to action?, in: Brand, U., Bullard, N., Lander, E., Mueller, T. (Eds.), Contours of Climate Justice: Ideas for shaping new climate and energy politics. Critical Currents. Dag Hammarskjöld Foundation, Uppsala.

Brydon-Miller, M., Greenwood, D., Maguire, P., 2003. Why action research? Action Research 1 (1), 928.

Celata, F., Sanna, V.S., 2012. The post-political ecology of protected areas: nature, social justice and political conflicts in Galápagos Islands. Local Environment: The International Journal of Justice and Sustainability 17 (9), 1-14.

Chatterton, P., Featherstone, D., Routledge, P., 2013. Articulating Climate Justice in Copenhagen: Antagonism, the Commons, and Solidarity. Antipode 45 (3), 602-620.

CJA-Booklet, 2009. Why climate change is not an environmental issue.

CJA-Leaflet, 2009a. Hit the production.

CJA-Leaflet, 2009b. It is not just about CO2.

CJA-Leaflet, 2009c. Reclaim Power. Pushing for climate justice.

CJA-Leaflet, 2009d. System change! Not climate change. Take action in Copenhagen!

ClimateCollective, 2009. Action Guide to COP15.

Cook, I.R., Swyngedouw, E., 2012. Cities, Social Cohesion and the Environment: Towards a Future Research Agenda. Urban Studies 49 (9), 1959-1979.

COP15zine, 2009. Dealing with distractions. Confronting Green Capitalism in Copenhagen \& Beyond.

Crouch, C., 2004. Post-Democracy. Polity Press, Cambridge.

De Lucia, V., 2009. Hegemony and Climate Justice: A critical Analysis, in: Böhm, S., Dabhi, S. (Eds.), Upsetting the Offset. The Political Economy of Carbon Markets. MayFlyBooks, London.

Demeritt, D., 2001. The Construction of Global Warming and the Politics of Science. Annals of the Association of American Geographers 91 (2), 307-337.

Dikeç, M., 2005. Space, politics, and the political. Environment and Planning D: Society and Space 23, 171-188.

Dikeç, M., 2012. Space as a mode of political thinking. Geoforum 43, 669-676.

Dikeç, M., 2013. Beginners and equals: political subjectivity in Arendt and Rancière. Transactions of the Institute of British Geographers 38 (1), 78-90.

Featherstone, D., 2013. The Contested Politics of Climate Change and the Crisis of Neo-liberalism. ACME. An International E-Journal for Critical Geographies 12 (1), 44-64.

Featherstone, D., Korf, B., 2012. Introduction: Space, contestation and the political. Geoforum 43 (4), 663-668.

Goeminne, G., 2010. Climate Policy is Dead, Long Live Climate Politics! Ethics, Place and Environment $13(2), 207-214$.

Goeminne, G., 2012. Lost in Translation: Climate Denial and the Return of the Political. Global Environmental Politics 12 (2), 1-8. 
Hallward, P., 2006. Staging Equality. On Rancière's Theatrocracy. New Left Review (37), 109-129.

Howarth, D., 2000. Discourse Open University Press, Buckingham.

Howarth, D., Norval, A.J., Stavrakakis, Y., 2000. Discourse theory and political analysis. Identities, hegemonies and social change. University Press, Manchester.

Howarth, D., Stavrakakis, Y., 2000. Introducing discourse theory and political analysis, in: Howarth, D., Norval, A.J., Stavrakakis, Y. (Eds.), Discourse theory and political analysis. Identities, hegemonies and social change. University Press, Manchester.

Jensen, B.B., 2002. Knowledge, Action and Pro-environmental Behaviour. Environmental Education Research 8 (3), 325-334.

Jensen, B.B., 2004. Environmental and health education viewed from an action-oriented perspective: a case from Denmark. Journal of Curriculum Studies 36 (4), 405 - 425.

Jensen, D., 2009. Forget shorter showers. Why personal change does not equal political change, in: COP15zine (Ed.), Dealing with distractions. Confronting Green Capitalism in Copenhagen \& Beyond.

Kenis, A., Lievens, M. 2014. Searching for 'the political' in environmental politics. Environmental Politics. Published online: 14 Jan 2014. DOI: 10.1080/09644016.2013.870067.

Kenis, A., Lievens, M. Forthcoming. Greening the economy or economizing the green project? When environmental concerns are turned into means to save the market. Review of Radical Political Economics.

Kenis, A., Mathijs, E. 2009. From Individual to Collective Change and Beyond: Ecological Citizenship and Politicisation. Conference of the European Sociological Association. Lisbon.

Kenis, A., Mathijs, E. Forthcoming. (De)politicising the Local: The Case of the Transition Towns Movement in Flanders (Belgium). Journal of Rural Studies.

Kenis, A., Mathijs, E. 2012. Beyond individual behaviour change: the role of power, knowledge and strategy in tackling climate change. Environmental Education Research, 18 (1), 45-65.

Laclau, E., 1990. New Reflections on the Revolution of our Time. Verso, London.

Laclau, E., 2005. On Populist Reason. Verso, London.

Laclau, E., Mouffe, C., 2001. Hegemony and Socialist Strategy: towards a Radical Democratic Politics Verso, London.

Marchart, O., 2007. Post-Foundational Political Thought: Political Difference in Nancy, Lefort, Badiou and Laclau. Edinburgh University Press, Edinburgh.

Mason, K., Whitehead, M., 2012. Transition Urbanism and the Contested Politics of Ethical Place Making. Antipode 44 (2), 493-516.

Mouffe, C., 2000. The Democratic Paradox. Verso, London.

Mouffe, C., 2002a. Politics and passions. The stakes of democracy. CSD Perspectives, London.

Mouffe, C., 2002b. Which Public Sphere for a Democratic Society? Theoria: A Journal of Social and Political Theory (99), 55-65.

Mouffe, C., 2005. The Return of the Political. Verso, London.

Mouffe, C., 2006. On the political. Routledge, London.

Müller, T., 2008. The movement is dead, long live the movement! Turbulence 4, 48-54.

Müller, T., Passadakis, A., 2009. Twenty Thesis Against Green Capitalism, in: COP15zine (Ed.), Dealing with distractions. Confronting Green Capitalism in Copenhagen \& Beyond.

Neal, S., 2013. Transition culture: Politics, localities and ruralities. Journal of Rural Studies 32, 60-69. North, P., 2010. Eco-Localisation as a progressive response to peak oil and climate change - a sympathetic critique. Geoforum 41 (4), 585-594. 
Oosterlynck, S., Swyngedouw, E., 2010. Noise reduction: the postpolitical quandary of night flights at Brussels airport. Environment and Planning A 42 (7), 1577 - 1594.

Patton, M.Q., 2002. Qualitative Research \& Evaluation Methods. Sage, London.

Rancière, J., 1998. Disagreement: Politics and philosophy. University of Minnesota Press, Minneapolis. Rancière, J., 2001. Ten Theses on Politics, Theory \& Event.

Rancière, J., 2006. Hatred of democracy. Verso, London.

Rancière, J., 2007a. On the Shores of Politics. Verso, London.

Rancière, J., 2007b. The Politics of Aesthetics. Continuum, London.

Reason, P., Bradbury, H., 2008. The SAGE Handbook of Action Research. Participative Inquiry and Practice. SAGE Publications, London.

Sumburn, P., 2010. A New Weather Front, in: Turbulence Collective (Ed.), What Would it Mean to Win? PM Press, Oakland.

Swyngedouw, E., 2007. Impossible "Sustainability" and the Postpolitical Condition, in: Krueger, R., Gibbs, D. (Eds.), The Sustainable Development Paradox. The Guilford Press, London.

Swyngedouw, E., 2010a. Apocalypse Forever? Theory, Culture \& Society 27 (2-3), 213-232.

Swyngedouw, E., 2010b. Trouble with Nature: 'Ecology as the New Opium for the Masses', in: Healey, P., Hillier, J. (Eds.), Conceptual Challenges for Planning Theory. London, Ashgate, pp. 299 - 320.

Swyngedouw, E., 2011. Interrogating post-democratization: Reclaiming egalitarian political spaces. Political Geography 30 (7), 370-380.

Swyngedouw, E., 2013. The Non-political Politics of Climate Change. ACME: An International E-Journal of Critical Geographies 12 (1), 1-8.

The Autonomous Geographies Collective, 2010. Beyond Scholar Activism: Making Strategic Interventions Inside and Outside the Neoliberal University. ACME: An International E-Journal for Critical Geographies 9 (2), 245-275.

Urry, J., 2011. Climate Change and Society. Polity Press, Cambridge.

Virtanen, M., 2009. Six Arguments against Alternative Industrialism in: COP15zine (Ed.), Dealing with distractions. Confronting Green Capitalism in Copenhagen \& Beyond.

Wynne, B., 2010. Strange Weather, Again: Climate Science as Political Art. Theory, Culture \& Society 27, 289-305.

Žižek, S., 2000. The Ticklish Subject. The Absent Centre of Political Ontology. Verso, London.

Žižek, S., 2008. Censorship Today: Violence, or Ecology as a New Opium for the Masses. http://www.lacan.com/zizecology1.htm. 